DOI: https://doi.org/10.24144/2409-6857.2021.1(57).80-84

УДК УДК 339.92:332.1

Габчак Н.Ф., Дубіс Л.Ф., Маляр Е.М.

\title{
КРИТЕРІЇ ВИОКРЕМЛЕННЯ ПЕРСПЕКТИВНИХ ПУНКТІВ ПРОПУСКУ УКРАЇНСЬКО- УГОРСЬКОГО КОРДОНУ В МЕЖАХ ЗАКАРПАТТЯ
}

В статті досліджено особливості транспортної інфраструктури на украӥнсько-угорській ділянці в межах Закарпатської області (Украӥна). Обтрунтовано актуальність досліджень та необхідність вдосконалення існуючої транспортної мережі, а також важливість технічного забезпечення пасажирота вантажопотоків на території дослідження. Доведено, щуо Угорщина є головним партнером у зовнішньоекономічних зв'язках регіону. Проаналізовано основні тенденції розвитку регіональної політики двох країн та розглянуто проблеми та перспективи щуодо відкриття нових пунктів пропуску на украӥнсько-угорській діляниі кордону в межах Закарпаття.

Ключові слова: транспортна інфраструктура, зовнішньоекономічна діяльність, пункти пропуску, регіональна політика.

Постановка проблеми. Транзитність України та іiі розташування в регіоні Центрально-Східної Європи доводить важливість розбудови транспортної мережі на транскордонних ділянках. Історичні, економічні, культурні та соціальні зв'язки зумовлюють активізацію транспортного співробітництва прикордонних територій [1].

Закарпаття дотичне до чотирьох країн Європейського Союзу (Польща, Словаччина, Угорщина, Румунія), довжиною кордону 460 км, що зумовлює необхідність вдосконалення транспортної інфраструктури, технічне забезпечення перевезення вантажів та пасажирів.
Найбільшими показниками зовнішньоекономічної діяльності виокремлюється українсько-угорська ділянка кордону в межах Закарпатської області. Так, зовнішньоекономічна діяльність території дослідження повністю зорієнтована на ринок Європейського Союзу. У 2019 році на країни ЄС припадало 95,5\% товарного експорту цього регіону, тоді як у середньому в регіонах України - лише 42,6\% [2]. Ключову роль відіграє передусім, Угорщина, на яку у 2019 році припадало 56,1\% товарного експорту регіону (рис.1). Область забезпечила $56,5 \%$ українського експорту до Угорщини, який загалом становив 1646,3 млн. дол. США [2].

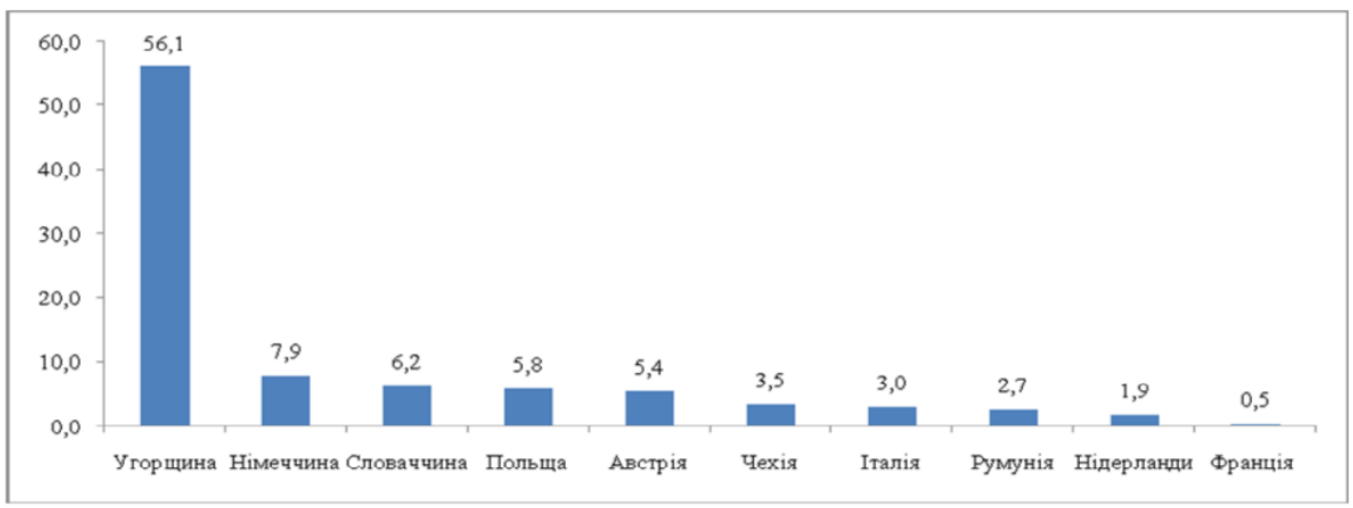

Рис.1. Географічна структура експорту товарів із Закарпатської області у 2019 році, \% [2]

(C) Габчак Н.Ф., к. геогр. н, доц., доцент кафедри туризму ДВНЗ «Ужгородський національний університет», e-mail: habchak.nf@gmail.com

Дубіс Л. Ф., д. геогр.н., проф., Люблінський католицький університет Івана Павла II, Польща, Львівський національний університет імені Івана Франка, завідувачка кафедри геоморфології та палеогеографіï, Україна e-mail: lida.dubis@gmail.com Маляр Е.М., ст. викл. кафедри туризму ДВНЗ «Ужгородський національний університет», e-mail: dzki@ukr.net
Тому питання вдосконалення транспортних мереж як важливого чинника розвитку транскордонних регіонів стає все більш актуальним та відповідає основним тенденціям розвитку регіональної політики Закарпаття та України загалом.

Аналіз останніх досліджень та публікацій. Особливості транспортної мережі та іiі роль у міжрегіональному та транскордонному співробітництві досліджували науковці Інституту 
регіональних досліджень НАН України у містах Львів та Київ, а також ряд вітчизняних вчених, а саме: М. Долішній, 3. Герасимчук, Л. Корольчук, I. Артьомов, Н. Габчак, Л. Дубіс, I. Журба, Н. Ільченко, Е.Маляр та інші. Праці вищезазначених науковців розкривають суть проблем використання та ефективність експлуатації транспортної інфраструктури та шляхи іiі вдосконалення в межах досліджуваної території.

Формулювання цілей статті. Метою статті $\epsilon$ обгрунтування необхідності розбудови транскордонної мережі на українсько-угорській ділянці державного кордону в межах Закарпатської області.
Опис основного матеріалу дослідження. Аналізуючи існуючі економіко-регіональні характеристики пунктів пропуску на перетині лінії державного кордону України з Угорщиною в межах транскордонних територій Закарпатської області, можливо надати вихідні дані для створення нових та удосконалення існуючих пунктів пропуску кордону. В зазначених транскордонних територіях існує ціла низка перспективних пунктів пропуску, таких як: «Бадалово, Барієво - Сатмарчеке, Тісакород», «Велика Паладь - Нодьгодош», «Велика Паладь Мала Паладь (Кишпалад)», «Гетен-Тисокеречень», «Дийда - Берегдароц», «Соловка Тісасентмартон» та «Соловка- Еперєшке» (рис.2).

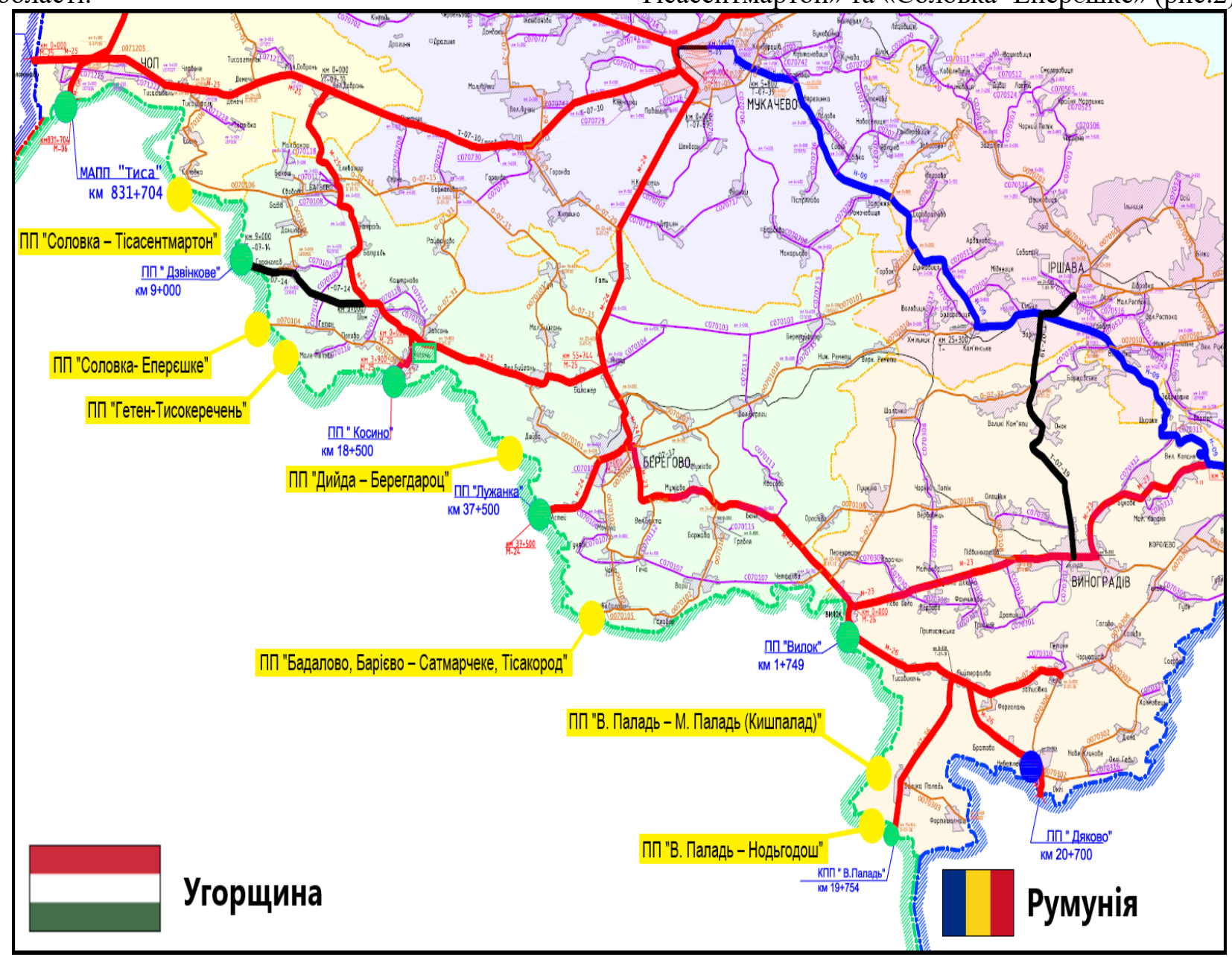

Рис. 2 Перспективні пункти пропуску на українсько-угорській ділянці кордону в межах Закарпатської області*

*Джерело: авторська розробка Маляр Е., Салюк-Кравченко О.

Одним із таких пунктів пропуску (далі - ПП) $\epsilon$ «Бадалово, Барієво - Сатмарчеке, Тісакород», який в перспективі повинен стати переправою через річку Тиса в селищі Бадалово Берегівського району. Неподалік розташовані такі населені пункти як с. Астей, с. Боржава, с. Бене, с. Вари, с. Велика Бакта, с. Галабор, с. Гуняді, с. Геча, с. Квасово, с. Мочола та с. Чома, де проживає більше як 12 тисяч населення і районний центр місто Берегово розташований за 25 км до зазначеного об' єкту.

В Берегівському районі працюють промислові підприємства, найбільшими 3 них $\epsilon$ ПрАТ «Берегівський кар'єр», СП ТОВ «Керам надра», ПП «Кінга», ТОВ «Кнюппель Ферпакунг» та інші. 
Якщо розглянути аналогічний пункт пропуску зі сторони Угорщини, то він буде знаходитись в селищі Сатм арчеке (Szatmárcseke) 3 населенням 1500 осіб та невеликими поселеннями: Túristvándi, Tisztaberek, Tarpa, Nagyar, Tivadar та Kisar, 3 кількістю населення приблизно 6 тисяч осіб.

Що стосується інфраструктурної складової перспективного ПП «Бадалово, Барієво Сатмарчеке, Тісакород», то ключову роль тут відіграють автомобільні шляхи: зі сторони України відстань до доріг державного значення до М-23 - від 10 км (по дорозі С 070112) до 13 км (по дорозі О 07102), до М-24 - 10 км (по дорозі С 070107); відстань до дороги європейського значення до Е81 - 10 км, а зі сторони Угорщини: відстань до доріг державного значення до 41 - від 22 км (від с. Сатмарчеке) до 33 км (від с. Тісакород), до 491 - від 9 км (від с. Сатмарчеке) до 11 км (від с. Тісакород); відстань до автомагістралі М3 - від 38 км (від с. Сатмарчеке) до 40 км (від с. Тісакород) [2]. Поруч функціонують такі пункти пропуску як «Лужанка» та «Вилок» пропускна спроможність яких в декілька разів перевищує нормовану спроможність руху пасажирів та вантажів. Але, звичайно, перспективний ПП «Бадалово, Барієво - Сатмарчеке, Тісакород» має і слабкі сторони реалізації. Має доволі високий ризик щодо підтоплення так як розміщуватиметься у гирлі річки Тиса. На даний час реалізуються проєкти протиповеневого захисту, що мінімізує відповідний ризик.

Існує певна кількість нормативних документів які передбачають побудову перспективного ПП «Бадалово, Барієво - Сатмарчеке, Тісакород» в стратегіях та програмах регіонального та національного рівня, таких як Програми прикордонного співробітництва «Європейський інструмент сусідства та партнерства. Україна Словаччина - Угорщина - Румунія» [6] та Програма розвитку прикордонної інфраструктури в Закарпатській області на 2018 - 2022 роки [4]. Додатково реалізацію проєкту передбачено в рішенні уряду Угорщини «Про організацію транспортної інфраструктури на угорськоукраїнському кордоні» (від 29.12.2017 року № 2130/2017 (XII. 29.), протоколом про наміри щодо всебічного розвитку пунктів пропуску та інфраструктури на державному кордоні між Україною та Угорщиною від 24.11.2016 року та декларації намірів щодо комплексного розвитку автодорожніх пунктів перетину державного кордону між Угорщиною та Україною від 28.03.2013 року.
Наступним перспективним ПП $є$ «Велика Паладь - Нодьгодош», який за підрахунками спеціалістів буде мати пропускну спроможність на в'їзд та виїзд на добу до 300 одиниць транспортних засобів. На даний час закінчено капітальний ремонт 11,5 км під'їзної автомобільної дороги зі сторони української території, а з угорської - побудовано дорогу між населеним пунктом Нодьгодош та державним кордоном України. Інфраструктурна складова це впершу чергу існуючі автомобільні шляхи, так, зі сторони України відстань до доріг міжнародного значення до М-23 - 19 км (від с. Велика Паладь) до М-26 - 8 км (від с. Велика Паладь); відстань до дороги європейського значення до Е-81 - 19 км (від с. Велика Паладь), а зі сторони Угорщини відстань до дороги державного значення 491 17 км (від Нодьгодош); відстань до автомагістралі М3 - 68 км (від Нодьгодош) [2].

Діючі сусідні пункти пропуску - це «Вилок» (22 км від перспективного ПП) та ПП «Дякове» (31 км від перспективного ПП) на кордоні 3 Румунією. Звичайно побудова нового значно розвантажить діючі пункти пропуску.

Нормативно-правова сторона відкриття ПП «Велика Паладь - Нодьгодош» представлена в наступних документах регіонального та національного рівня, a саме: Програма прикордонного співробітництва «Європейський інструмент сусідства та партнерства. Україна Словаччина - Угорщина - Румунія» [6], Програма розвитку прикордонної інфраструктури в Закарпатській області на 2018 - 2022 роки [4], регіональна Стратегія розвитку Закарпатської області на період 2021-2027 років [9].

Наступний для дослідження перспективний ПП «Велика Паладь - Мала Паладь (Кишпалад)», повинен розміщуватись в селищі Велика Паладь Виноградівського району. На даній території розміщене родовище геотермальних вод, яке приваблює туристів та вже зацікавило інвесторів щодо розвитку туристичного бізнесу. Найближчими населеними пунктами зі сторони України є такі села як: Пийтерфолво, Тисобикень, Затисівка, Ботар та Неветленфолу, а із сторони території Угорщини - Kishódos, Мала Паладь (Kispalád), Botpalád, Magosliget, Uszka, Tiszabecs, Túrricse, Tisztaberek та Csaholc. Це в майбутньому не тільки покращить зовнішньоекономічні зв'язки обох прикордонних територій, а й покращить економічно-соціальний рівень життя населення. 3 головних переваг перспективного ПП $є$ те, що автомобільний шлях міжнародного значення М-26 забезпечить під'їзд до перспективного ПП, який пролягає через Закарпатську область. 
Діючі сусідні ПП через лінію державного кордону - це ПП «Вилок» та ПП «Дякове» розвантажили б наявний пасажиро- та вантажообіг.

Відповідні нормативно-правові акти, які передбачають відкриття ПП «Велика Паладь Мала Паладь (Кишпалад)» містяться в договорі між урядом України та урядом Угорщини про надання кредиту на умовах пов'язаної допомоги (ратифіковано Законом України від 23.03.2017 року № 1978-VIII) [9]. Стратегії та програми регіонального та національного рівня реалізація заходів, щодо створення перспективного ПП проілюстровані в Програмі прикордонного співробітництва «Європейський інструмент сусідства та партнерства Україна - Словаччина Угорщина - Румунія» [8] та Програмі розвитку прикордонної інфраструктури в Закарпатській області на 2018 - 2022 роки [6].

Поблизу селища Гетен Берегівського району в селищі Тисокеречень 3 угорської сторони планується побудувати черговий пункт пропуску «Гетен-Тисокеречень». Навколо селища Тисокеречень розміщено чимало населених пунктів (Гюре, Ораньошапаті, Тішадони та Матюш) та 9 індустріальних парків (найбільші Sátoraljaújhelyi Ipari Park, Mátészalka Ipari Park, Nyírbátori Ipari Park та Balkányi Ipari Park) та місто Ньїредьгаза, який $\epsilon$ центром Саболч-СатмарБерег медьє. Саме селище Тисокеречень має доволі розвинену транспортну інфраструктуру, наприклад 23 км становить відстань до європейського автошляху Е573 та 22 км до європейського автошляху Е 579.

Щодо українського селища Гетен, то поблизу нього знаходяться с. Попово та Косино знаменитий курорт геотермальних вод.

Не менш важливим в майбутньому повинен стати ПП «Дийда - Берегдароц» із запланованою пропускною спроможністю на в їзд та виїзд на добу більше 1000 одиниць транспортних засобів.

Також заплановано 3 української сторони відкрити в селищі Дийда Берегівського району ще один ПП, який буде побудовано за 7 км від Берегово та за 65 км від обласного центру міста Ужгорода. В недалекому майбутньому в селищі Дийда заплановано побудувати індустріальний парк. $\mathcal{C}$ і на території селища свій аквапарк Horus, озеро Дідове та орнітологічний сезонний заказник місцевого значення, що підсилює рекреаційне значення даної території.

Аналогічно зі сторони Угорщини перспективний ПП буде розміщений в селищі Береграроц (Beregdaroc), найближчими населеними пунктами від селища Beregdaroc $є$ (до 17 км): Barabác, Beregsurány, Mapoknani, Csaroda тa Gelenés.

В програмах регіонального рівня реалізація заходів, щодо створення перспективного ПП, вказані в Програмі розвитку прикордонної інфраструктури в Закарпатській області на 2018 2022 роки [6]. На локальному рівні стратегій та програм побудова перспективного ПП представлена в Схеми планування території Берегівського району [7].

Транскордонні території Закарпатської області мають свої унікальні географічні та інфраструктурні особливості та відкривають значні можливості розширення зовнішньоекономічних зв'язків на українськоугорській ділянці кордону.

$\begin{array}{llc}\text { Висновки } & \text { i перспективи подальших } \\ \text { Гесліджень. } & \text { Географічна } & \text { близькість }\end{array}$ досліджень. Географічна близькість складової - Закарпатської області сприяє розвитку зовнішньоекономічних зв'язків, підвищуватиме економічний розвиток депресивних районів та виокремить об'єктивну необхідність відкриття нових пунктів пропуску вздовж лінії державного кордону.

\section{ПЕРЕЛІК ВИКОРИСТАНИХ ДЖЕРЕЛ}

1. Габчак Н., Маляр Е. Транспортна мережа як важливий чинник розвитку транскордонних регіонів (на прикладі Закарпатської області). Науковий вісник Ужгородського університету. Збірник наукових праць. Серія: Економіка - Ужгород, 2020.- С. 61-68.

2. Закарпатська область: особливості, умови та перспективи соціально-економічного розвитку /Іщук С.О., Созанський Л.Й./ науково-аналітична записка НАН України. Інститут регіональних досліджень. - Львів, 2019. C.21.

3. Про автомобільні дороги: Закон України від 08.09.2005 p. № 2862-IV. URL: https://zakon.rada.gov.ua/laws/show/2862-15\#Техt (дата звернення: 20.02.2020).

4. Про охорону культурної спадщини: Закон України від 08.06.2000 p. № 1805-III. URL: https://zakon.rada.gov.ua/laws/show/1805-14\#Техt (дата звернення: 25.01.2020).

5. Про охорону навколишнього природного середовища: Закон України від 25.06.1991 p. № 1264-XII. URL: https://zakon.rada.gov.ua/laws/show/1264-12\#Tеxt (дата звернення: 27.01.2020).

6. Про регулювання містобудівної діяльності: Закон України від 17.02.2011 p. № 3038-VI. URL: https://zakon.rada.gov.ua/laws/show/3038-17\#Text (дата звернення: 20.01.2020). 
7. Про стимулювання розвитку регіонів: Закон України від 08.09.2005 p. № 2850-IV. URL: https://zakon.rada.gov.ua/laws/show/2850-15\#Text (дата звернення: 18.01.2020).

8. Про транскордонне співробітництво: Закон України від 24.06. 2004 p. № 1861-IV. URL: https://zakon.rada.gov.ua/laws/show/1861-15\#Text (дата звернення: 08.01.2020).

9. Про туризм: Закон України від 15.09.1995 р. № 324/95-BP. URL: https://zakon.rada.gov.ua/laws/show/324/95вр\#Техt (дата звернення: 15.02.2020).

\section{REFERENCES}

1. Habchak, N., \& Maliar, E. (2020) Transportna merezha yak vazhlyvyi chynnyk rozvytku transkordonnykh rehioniv (na prykladi Zakarpatskoi oblasti) [Transport network as an important factor in the development of cross-border regions (on the example of the Transcarpathian region)]. Naukovyi visnyk Uzhhorodskoho universytetu. Seriia: Ekonomika Scientific Bulletin of Uzhhorod University.. Series: Economics, 61-68 [in Ukrainian].

2. Ishchuk, S.O., \& Sozanskyi, L.I. (2019). Zakarpatska oblast: osoblyvosti, umovy ta perspektyvy sotsialnoekonomichnoho rozvytku [Transcarpathian region: features, conditions and prospects of socio-economic development] Naukovo-analitychna zapyska NAN Ukrainy. Instytut rehionalnykh doslidzhen, Lviv [in Ukrainian].

3. Pro avtomobilni dorohy: Zakon Ukrayiny vid 08.09.2005 r. № 2862-IV [Law of Ukraine on the roads № 2862-IV, 2005, September 08]. (2005). Retrieved from: https://zakon.rada.gov.ua/laws/show/2862-15\#Text [in Ukrainian].

4. Pro okhoronu kulturnoyi spadshchyny: Zakon Ukrayiny vid 08.06.2000 r. № 1805-III [Law of Ukraine on the protection of cultural heritage № 1805-III, 2000, June 08]. (2000). Retrieved from: https://zakon.rada.gov.ua/laws/show/1805-14\#Text [in Ukrainian].

5. Pro okhoronu navkolyshnoho pryrodnoho seredovyshcha: Zakon Ukrayiny vid 25.06.1991 r. № 1264-XII [Law of Ukraine on the environmental protection № 1264-XII, 1991, June 25]. (1991). Retrieved from: https://zakon.rada.gov.ua/laws/show/1264-12\#Text [in Ukrainian].

6. Pro rehulyuvannya mistobudivnoyi diyalnosti: Zakon Ukrayiny vid 17.02.2011 r. № 3038-VI. [Law of Ukraine on the regulation of urban planning activities № 3038-VI, 2011, February 17]. (2011). Retrieved from: https://zakon.rada.gov.ua/laws/show/3038-17\#Text [in Ukrainian].

7. Pro stymulyuvannya rozvytku rehioniv: Zakon Ukrayiny vid 08.09.2005 r. № 2850-IV [Law of Ukraine on the stimulating the development of regions № 2850-IV, 2005, September 08]. (2005). Retrieved from: https://zakon.rada.gov.ua/laws/show/2850-15\#Text [in Ukrainian].

8. Pro transkordonne spivrobitnytstvo: Zakon Ukrayiny vid 24.06. 2004 r. № 1861-IV [Law of Ukraine on the crossborder cooperation № 1861-IV, 2004, June 24]. (2004). Retrieved from: https://zakon.rada.gov.ua/laws/show/186115\#Text ([in Ukrainian].

9. Pro turyzm: Zakon Ukrayiny vid 15.09.1995 r. № 324/95-VR [Law of Ukraine on the tourism № 324/95-VR, 1995, September 15]. (1995). Retrieved from: https://zakon.rada.gov.ua/laws/show/324/95-vr\#Text [in Ukrainian].

Отримано 24.02.2021 